\title{
Leiomyosarcoma and Endometrial Stromal Sarcoma Pathologic TNM Finding v7
}

National Cancer Institute

\section{Source}

National Cancer Institute. Leiomyosarcoma and Endometrial Stromal Sarcoma

Pathologic TNM Finding v7. NCI Thesaurus. Code C89582.

A pathologic finding about one or more characteristics of leiomyosarcoma and endometrial stromal sarcoma, following the rules of the TNM AJCC V7 classification system. 